\title{
Holistiese verstaan teenoor analitiese verstaan in Bybelse hermeneutiek
}

\author{
B van Niekerk \& A G van Aarde \\ Universiteit van Pretoria
}

\begin{abstract}
Holistic interpretation compared to analytical interpretation in biblical hermeneutics

In recent years there has been growing interest in a holistic approach to biblical hermeneutics. If this holistic approach leads us to a new, post-critical, macro-paradigmatic model, the concequences for hermeneutics indeed for theology as a whole - should be examined. Mechanism and holism should be explained in terms of each other, to compare their possible advantages and disadvantages. Finally, the relevance of Christianity amid changing visions of reality is discussed.
\end{abstract}

Vraagstelling

In hierdie artikel word gepoog om die parameters van die sogenaamde holistiese verstaan te verken en wel in die lig van die parameters van wat as die analitiese verstaan bekend staan. Die vraagstelling wat sodoende aan die orde gestel word, is om deur te dring na die gevolge van wat 'n holistiese verstaan vir die Bybelse hermeneutiek kan inhou. Die ondersoek begin met die vraag hoe die onderskeie benaderings se parameters verskil. Die werkwyse sal dus wees om die twee stelle parameters in terme van mekaar te verduidelik. In hierdie artikel word dan ook van die standpunt uitgegaan dat ' $n$ holistiese verstaan paradoksaal afskeid geneem het van die analitiese verstaan waarvan dit terselfdertyd afhanklik bly.

In die artikel kom konsepte soos meganisme, holisme, objektiwisme, subjektiwisme, metafisika, kenteorieë en die nuwe fisika ter sprake. In die hantering van hierdie konsepte sal gepoog word om aan te toon dat daar nog nie 'n volledige para-

- Ingedien en aanvaar as deel van die vereistes vir die BD-graad (1990), Fakulteit Teologie (Afd A), Universiteit van Pretoria, onder leiding van prof dr A G van Aarde. 
digmaverskuiwing plaasgevind het van die analitiese na die holistiese verstaan nie en dat, veral in terme van die Godsbegrip, die debat nog nie voldoende gevoer is nie.

Die bespreking in hierdie artikel sal stelselmatig aan die hand van sekere begrippe geskied. Dit het begripverheldering ten doel, maar sal ook poog om die gestelde probleem aan die orde te stel en te bespreek.

\section{Verstaan}

'Verstaan' is 'n aangeleentheid waarbinne die kennende subjek die kenbare objek bestudeer om tot insig van laasgenoemde se inhoud en aard te kom. 'Verstaan' geskied volgens die Kuhniaanse kenteorie (kyk later) altyd binne die parameters van 'n bepaalde paradigma.

\section{'Kennende subjek' en 'kenbare objek'}

Deur die geskiedenis heen is binne verskillende verstaansmodelle verskillende prominensie aan die rolle van die kennende (bestuderende) subjek en die kenbare (bestudeerbare) objek in die verstaansproses gegee. Descartes het tussen die mens en die empiriese werklikheid onderskei, sodat daar 'n dualisme ontstaan het tussen subjek en objek. Sy invloed is haas onmeetbaar, aangesien op byna alle terreine van wetenskapsbeoefening die vorige paradigma laat vaar is ten gunste van die meganistiese model, soos Descartes se teorie bekend sou staan.

Die terme 'subjek' en 'objek' moet nie verwar word met die terme 'subjektivisme/relativisme' en 'objektivisme' nie. Die primêre uitgangspunt of klem in die objektivistiese model is die rol wat die objek in navorsing vervul. Resultate word ook as objektief waar en geldig aangebied. Die rol van die subjek is onderwaardeer, daarom kon twee persone op verskillende gegewe tye dieselfde resultate bereik. Persoonlike vooronderstellings en die rol wat dit in navorsing speel, is nie in ag geneem nie. Bernstein (1985:8) meen dat ten grondslag van dié (objektivistiese) werkwyse 'n veronderstelling lê dat 'unless we can ground philosophy, knowledge, or language in a rigorous manner we can never avoid scepticism'. Subjektivisme, daarenteen, bepleit die erkenning dat in the final analysis all such concepts must be understood as relative to a specific conceptual scheme, theoretical framework, paradigm, form of life, society or culture' (Bernstein 1985:8).

In die meganistiese werklikheidsverstaan, of heersende paradigma, voer Willem Vorster aan dat interpretasie relasioneel geskied; met ander woorde, die objek en die subjek speel albei 'n belangrike rol. Die wetenskap poog egter nog om die resultate as objektief te laat blyk (Vorster 1988:34). Die historiese kritiek is, volgens hom, ' $n$ voorbeeld van die meganistiese model se uitwerking in die beofening van 
die teologie. Die uitgangspunt van die historiese kritiek het onder andere ook klem gelê op die gedissekteerde dele ten koste van die geheel: 'n kenmerk van die Cartesiaanse werkwyse.

Hierteenoor is die resultate en uitsprake van die vitalistiese raamwerk of animisme subjektief van aard. Van Aarde (1988:58) sien in die voorgestelde holistiese model wat organismies van aard is, nie vooruitgang in terme van wetenskaplikheid nie, maar agteruitgang, aangesien dit 'n poging sou wees om agter die meganistiese model heen terug te gryp na kenmerke van die animisme, onder andere 'n relativisme en subjektivisme. Hierdie subjektivisme sou egter 'n volgende konsekwensie hê,

- naamlik dat dit op 'n monistiese metafisika, of wat die godsdiens betref, op panteisme neerkom (Van Aarde 1988:58; 1990b:12). Die voorgestelde holisme is monisties in praktyk, teenoor die Cartesiaanse dualisme of skeiding tussen subjek en objek. Monisme as vertrekpunt laat min ruimte vir (ook kwalitatiewe) onderskeid tussen mens en God, terwyl die nut van die Kantiaanse dialektiek binne die teologie is om die skeiding tussen God en mens in die vorm van relasieverhouding te oorbrug.

Soos met die meganistiese model, spruit die voorgestelde holistiese paradigma uit die resultate van die fisika. Wanneer wetenskaplikes probeer het om fotone (ligpartikels) waar te neem, het hulle telkens tot verskillende resultate gekom. Die waarnemingsakte van die wetenskaplike, of subjek, het die verskyningsgestalte van die objek verander. Die gevolg is dat die resultaat van waarneming nie voorspel kon word nie. Die teorie wat rondom hierdie eksperiment geformuleer is, staan bekend as Heisenberg se onsekerheidsprinsipe. 'We can never be sure of the exact location of a particle because our only means of seeing the particle - bombarding it with a photon - will change its location' (Talbot 1980:22). In hierdie geval is die rol van die subjek in die bestudering van die objek groter en allermins gedistansieerd en onbetrokke.

\section{Die Kuhniaanse kenteorie}

Kuhn kan beskou word as die vader van die terme 'paradigma'en 'wetenskaplike revolusies'. Die titel van sy opspraakwekkende boek is The structure of scientific revolutions. Hy gee aan die term 'paradigma' die inhoud van 'dissiplinêre matriks' (Kuhn 1970:182). Dit beteken kortliks dat die term dui op 'n raamwerk wat dikwels onbewustelik volgens ooreenkoms deur wetenskaplikes in 'n bepaalde wetenskap gebruik word. Hierdie raamwerk, ook die dominante paradigma genoem, beïnvloed sowel die persepsie as die resultaat van die 'normale wetenskap', of tewel die tydperk van wetenskapsbeoefening binne die afgespreekte raamwerk. 
Nuwe ontdekkings pas egter nie altyd in by die bestaande paradigma nie. Wanneer iets nie volgens verwagting by die spelreëls van die bepaalde paradigma inpas nie, ontstaan 'n anomalie. Die normale wetenskap gaan dan voort om die anomalieë aan allerlei toetse te onderwerp, totdat dit binne die paradigma verklaar kan word. As dit nie binne die paradigma verklaar kan word nie, moet die paradigma aangepas word om die anomalie te akkommodeer (Kuhn 1970:53). Wanneer anomalieë as uitsonderings geakkommodeer word binne 'n paradigma, word dit 'special cases' genoem.

Wanneer oplossings binne die bepaalde raamwerk toenemend moeiliker gevind word, of die anomalieë te veel word om die paradigma se geloofwaardigheid te verdedig, ontstaan 'n krisis of krisistydperk (kyk Kuhn 1970:77vv). Tydens hierdie tydperk word daar nuwe moontlike oplossings deur wetenskaplikes aan die hand gedoen; dit lei tot die ontstaan van 'n nuwe paradigma. Hierdie tydperk word die preparadigmatiese fase genoem.

Volgens hierdie teorie van die suksessie van radikaal verskillende paradigmas, is dit logies dat slegs een heersende paradigma binne die wetenskapsbeoefening van 'n bepaalde wetenskap geduld kan word. J P Martin gaan van die veronderstelling uit dat nie alleen kenmerke van die vorige paradigma by die volgende onderskeibaar is nie, maar dat die moontlikheid bestaan dat verskillende paradigmas naas mekaar kan 'oorleef'.

\section{Paradigma}

Martin se definisie van die begrip 'paradigma' sien soos volg daar uit: '[T]hey may be regarded in part as the psychic equivalent for modern scientifically educated people of ancient mythic patterns' (Martin 1987:373). Hy is geinteresseerd in die mate waartoe paradigmas as verwysingsraamwerke geld. Die implikasie is dat 'n 'paradigma' as verwysingsraamwerk geld, nie slegs vir die wetenskap nie, maar ook vir die gemeenskap van waaruit wetenskaplikes kom en waarheen hulle terugkeer. Dit lei Martin tot die bevinding dat daar sprake is van prekritiese of liberale parameters wat verband hou met vroeëre eras. Tans is daar sprake van postkritiese of postliberale parameters wat verband hou met die huidige wetenskapsfilosofieë en geskiedenis. Martin voer aan dat hierdie skemas (soos in die natuurwetenskappe aangewend) implikasies inhou vir die hermeneutiek, omdat hy van mening is dat een wetenskap se spelreëls van toepassing kan wees op 'n ander wetenskap. Verskillende paradigmas kan egter langs mekaar bestaan. Martin gebruik die begrip 'simbiotisiteit' om hierdie eienskap van die paradigma toe te lig. Hy lei hierdie eienskap af van die realiteit van verskillende vertrekpunte en (dus) verskillende resultate binne 'n enkele wetenskap. 
Beide Vorster en Martin is dit eens dat daar verskillende interpreteerders van die Bybel (bv feministiese, liberalisme ens) is, en dat hierdie interpretasiemoontlikhede heterargies funksioneer; die een het dus nie voorrang bo die ander nie. Martin voer die feit egter verder en meen dat daar verskillende heersende paradigmas ten grondslag van hierdie verskeidenheid le. In die simbiotiese benadering wat die wetenskappe in gemeen het, is een gemene benaderingsparameter vandag teenwoordig, naamlik postmoderniteit.

Postmoderniteit het die propagering van holistiese denke ten doel, teenoor die fragmentering en atomisme van die denke in lyn met Newton en Descartes. In 'n paar van die velde wat Martin noem, is die belangstelling nie meer in geîsoleerde besonderhede nie, maar meer in patrone en prosesse, byvoorbeeld in kosmologie, biologie en ekologie (Martin 1987:371). In die biologie het vorm en patroonmatigheid prioriteit bo materie, en kwaliteit bo kwantiteit. 'Pattern is qualitative and quantity does not determine pattern' (Martin 1987:371). Patrone en kwaliteite dui volgens die holistiese model, meer as die analise van die meganistiese model, op 'n eenheid onderliggend aan die aard van die objek. Hierdie patrone is egter nie staties nie, maar vorm 'n 'dans' (Martin 1987:371).

Hierdie patrone of patroonmatighede is uitgewerk deur die bioloog Gregory Bateson. Volgens Bateson (1972) is talle krisisse wat die wêtreld tans beleef, die resultaat van die 'split consciousness', oftewel die radikale skeiding tussen die subjek en objek, as parameter van die Cartesiaanse nalatenskap. Die mens het homself nie meer as deel van die ekosisteem gesien nie, en het daarom die aarde begin uitbuit. Talle pogings word in ons tyd aangewend om mense bewus te maak van veral ekologiese krisisse, hoewel die sosiologiese belangstellings wat deur die sestiger-en sewentigerjare van ons eeu aangewakker is, nie op die agtergrond geskuif is nie.

Die oorsaak van hierdie 'gedeelde bewussyn' is die Cartesiaanse persepsie van 'n dualistiese realiteit. Descartes maak 'n onderskeid tussen die res cogitans (die menslike denke) en dit wat die denke van die mens transendeer, die res extensa. Wat in die res extensa gebeur, raak die res cogitans nie, solank laasgenoemde nie daarvan bewus is of bewus wil word nie (kyk Descartes 1950:99vv). Die res cogitans (subjek) bestudeer die res extensa (objek) met behulp van metodiese reëls, met die gevolg dat objektiewe kennis van die objek die resultaat is (vgl Stumpf 1966:232234). Die oplossing van hierdie probleem is nie om aan die res extensa te verander nie, maar om die gedeelde bewussyn te verander na 'n deelnemende bewussyn.

Martin meen dat ons tans in 'n krisis (wat die kenmerk is van tussen-paradigmatiese verskuiwings) in die studie van die Bybel is. Hy noem dit die 'current methodological ferment'. Hierdie krisis is veroorsaak deur 'n verskuiwing van dominante 
wetenskaplike paradigmas in die Westerse kultuur (Martin 1987:370). Die krisis kan ook waargeneem word in 'n aantal ander voorbeelde wat Martin aanhaal.

In their interconnections these perceptions indicate an emerging holistic paradigm in which the relationships mind/body (nature), subject/object and whole/parts are being reinterpreted according to an interactive epistemology.

(Martin 1987:371)

Met betrekking tot Bybelse hermeneutiek sê Martin (1987:371): 'Thirst for a renewed sense of the whole underlies many concerns of biblical interpreters striving to come to terms with our current methodological ferment.' Daar is dus, volgens Martin, reeds aanduidings van 'n verskuiwing na 'n holistiese verstaan in Bybelse hermeneutiek.

Die drie paradigmas - vitalisme, meganisme en holisme (vgl ook Fowler 1989:8) - is onderskeibaar van mekaar, maar nie skeibaar nie. Hulle word in elk geval verstaan in terme van mekaar. Oorgang van een paradigma na ' $n$ ander is nie eensklaps nie, met die implikasie dat daar ná 'n 'paradigm shift' (Martin 1987:373) soms nog trekke van die vorige paradigma naspeurbaar is in die nuwe paradigma. So verwys die na-Copernikaanse mens byvoorbeeld steeds na die 'sonsopkoms' en die 'sonsondergang', terwyl hy weet dat die son stilstaan en die aarde draai. Net so kom daar nog trekke van die meganistiese paradigma in die holistiese paradigma voor, byvoorbeeld kritiese denke.

Berman sê dat, omdat daar 'n oorgang van een paradigma na 'n ander is, enigiemand wat in die laat-twintigste eeu van holisme praat, ' $n$ transisionele figuur is: 'So we need to speak of Mechanism and Holism together, acknowledging their currently ambiguous relations' (Martin 1987:375).

Die grondmetafoor waarmee die vitalistiese beskouing verduidelik kan word, is die lewende liggaam. Die meganistiese paradigma word met 'n masjien verduidelik: Die totale werklikheid word soos 'n masjien aanmekaar gesit. Die ratte van die masjien kan uitmekaar gehaal word, en afsonderlik bestudeer word. Elke rat of deel van die geheel wat bestudeer word, het afsonderlike kwaliteite of eienskappe wat hulle van die ander onderskei. By gebrek aan 'n aanvaarde metafoor vir die holistiese benadering, stel Martin (1987:373) 'n holograaf voor.

Nuwe paradigmas beïnvloed ook die mens se beskouings oor ander paradigmas en hulle resultate (Martin 1987:375). Hiérvoor word 'n 'deelnemende bewussyn' (participaring consciousness) benodig. (Later in die artikel word 'bewussyn' as parameter van die holistiese paradigma bespreek.) 


\section{Parameters}

Mense soos Galileo Galiei, René Descartes en Isaac Newton het bygedra om die parameters van die meganistiese paradigma te vorm. Parameters kan gedefinieer word as 'n 'scientific view of space, time, causality, ontology [of life and death], dynamics [entropy], analysis, etc' (Martin 1987:374). Die parameters van die natuurwetenskappe het ander wetenskappe beinvloed as gevolg van die rol wat hulle as deel van 'n groter verwysingsraamwerk in die samelewing as geheel gespeel het, beïnvloed. Omdat Bybelwetenskaplikes deel uitmaak van hierdie samelewing, is hulle ook daardeur.

Die klem op metode is in die heersende paradigma bepalend. Elke paradigma is egter afhanklik van een of ander beskouing wat ten grondslag lê van sy eie werkwyse. Die veronderstelling van die vitalisme was dat die werklikheid nie absoluut geken kan word nie, omdat slegs afskynsels van die werklikheid hulle aan die mens vertoon. Hierdie uitgangspunt is dus, wat metodologie betref, fenomenologies van aard. Kennis aangaande objekte is slegs moontlik tot die mate waartoe sulke objekte hulleself aan die subjek vertoon, of tot die mate waartoe objekte hulleself laat ken.

Die meganistiese paradigma is aan die ander kant meer optimisties oor die aard van sy bekombare kennis. Descartes (1950:70) omskryf in die volgende relatiewe bysin hiedie positiewe aard as hy meen dat kennis wel bekom kan word: '...wat my tot beskouings en stelreëls gelei het, waaruit ek 'n metode kon opbou, waarvolgens ek in staat mag wees om my kennis geleidelik uit te brei en algaande tot 'n hoogtepunt te kan voer...' (my vertaling; my beklemtoning). Sy beskouing kan as empiries of nominaal bestempel word. Die voorhande werklikheid is die finale werklikheid. Wat die derde paradigma betref, naamlik die holisme, is die metodologie wat eie daaraan is, struktureel van aard - nie in terme van 'n masjien nie, maar in terme van 'n lewende organisme.

Die verwysing na die strukturalistiese metodologie, eie aan die postkritiese holisme, het betrekking op die verband wat Martin (1987:377) lê tussen hedendaagse 'narrative [story] hermeneutics and Gregory Bateson's structural analysis of living crèatures of stories'. Strukturalisme in hierdie verband moet dus nie verwar word met byvoorbeeld Ferdinand de Saussure se strukturele linguistiek nie. Vanuit laasgenoemde perspektief word die essensie van eksistensie, of die betekenis van taal, teruggevind in die logosentriese metafisiese (referensiële/transendentale) relasie tussen die 'betekenaar' en die 'betekenende'. Hiervan het die postmoderne, dekonstruktiewe leesstrategie van iemand soos Derrida juis afskeid geneem (vgl Van Aarde 1990b:9). Deurdat betekenis op grond hiervan deurentyd verplaas word, omdat 
'referensiële betekenis' ontken word, word sinvol ruimte gebied aan die sogenaamde 'open end'-teorieë wat in die narratiewe hermeneutiek 'n belangrike rol vervul.

Benewens die 'metodologie' is ook die parameter 'interpretasie' belangrik vir die hermeneutiek. Die vitalisme het prekritiese interpretasie beoefen, terwyl die meganisme krities en die holisme postkrities is in terme van interpretasie. Die term 'postkrities' dui nie slegs op die vorige twee paradigmas wat herinterpreteer is en waaraan nuwe inhoude gegee is nie, maar is terselfdertyd 'n pro-term in soverre dit verwys na wat dit voorafgaan. Die term kan dus 'n verwysing wees na 'n kwaliteit van 'n nuwe paradigma wat besig is om te ontstaan. Die term 'post' wys dus tegelyk agtertoe en vorentoe (Martin 1987:371) en is nie (slegs) negatief te verstane nie.

Om die ander paradigmas as sodanig te begryp, word 'n 'deelnemende bewussyn' benodig (Martin 1987:375). Deelnemende bewussyn word gestel teenoor die gedeelde bewussyn of skeiding tussen subjek en objek in die meganistiese paradigma.

Die interpretasie van die Nuwe Testament kan in die fases 'prekrities', 'krities' en 'postkrities' ingedeel word. Die eerste fase (die vitalistiese periode) word normaalweg met 'n wissselterm 'simboliese verstaan' aangedui; die middelfase, ofte wel die meganistiese periode, word die 'analitiese verstaan' genoem (kyk Vorster 1988: 32); die voorgestelde term vir die postkritiese fase is die 'holistiese verstaan'. Laasgenoemde verteenwoordig 'n paradigmaverskuiwing wat Hans Küng (1984:21) as makro-paradigmaties van aard bestempel.

\section{Analitiese verstaan}

Die meganistiese paradigma vervang die animistiese (vitalistiese) paradigma en lê klem op die rede en rasionaliteit. Volgens hierdie paradigma is dit belangrik om die werklikheid te kan verklaar in terme van rasionele begrippe of toetsbare eksperimente. Van Arckel beskryf die eienskappe van die meganistiese model, wat die analitiese beoefening van hermeneutiek tot gevolg gehad het, aan die hand van agt parameters (kyk gekursiveerde terme): "The classic worldview was mechanistic in analogy, reductionistic in method, disciplinary in research, deterministic in outlook, static in perception, entropic in direction, dualistic in practice, and positivistic in determination of truth' (Van Arckel 1988:224; my beklemtoning).

Hierdie wêreldbeeld is gevorm aan die hand van die masjien as grondmetafoor. Die totale werklikheid en hoe verskillende elemente saamwerk in die kosmos is dus analogies gesproke meganisties van aard. Om hierdie analogie te vorm, is 'n vereenvoudigde metode gebruik, soos hierbo reeds na Descartes verwys is. Die vakdissiplines is skerp van mekaar onderskei (ook onder andere deur Descartes wat die presisie van die wiskunde verkies het). Dit het meegebring dat wetenskaplike ondersoe- 
ke staties eerder as dinamies in hulle waarneming geword het. Alle kennis is as akkumulatief gesien, en daar was 'n bepaalde rigting waarin die wetenskap sou ontwikkel. Daarom was die versameling van kennis en waarheid' positivisties gekleur.

Daar is reeds vroeër in die artikel na die dualistiese werkwyse verwys wat binne die meganisme gegeld het. Hierdie dualisme het veroorsaak dat 'n uitkyk van determinisme gegeld het. Die teorie dat elke oorsaak 'n gelyke gevolg sou hê, het 'n belangrike rol in hierdie paradigma gespeel en tot 'n groot mate word dié kousaliteitsbeginsel in die mediese wetenskap gehandhaaf (vgl Taylor 1983:34). Wat die transendensie betref, is dikwels (veral binne die ortodoksie) tot die gevolgtrekking gekom dat die wêreld deur God gepredestineer is.

Wat die verhouding van dele tot die geheel betref, kom 'n analitiese verstaan binne die raamwerk van die meganisme daarop neer dat die som van die dele die geheel vorm. Die somtotaal van die dele is dus gelyk aan die geheel. Ware kennis en verstaan van die geheel is hiervolgens moontlik deur uit die gedissekteerde dele 'n geheel te rekonstrueer. Dit is 'n voorstelling wat by Generaal J C Smuts in sy boek Holism and evolution voorkom (vgl Smuts 1987:19vv) en is 'n benadering met 'n atomistiese ingesteldheid. 'n Geheelbeeld van die studieobjek word gevorm deur die gedissekteerde dele weer sinteties aan mekaar te las. So gesien maak holisme, in die Kuhniaanse sin van die woord, 'n 'special case' van meganisme uit. Hierdie wêreldbeeld en benadering het groot invloed op die teologie en Bybelse hermeneutiek uitgeoefen (kyk Martin 1987:376). Die redaksie-historiese metode van eksegese as ' $n$ aspek van die histories-kritiese benaderingswyse in die eksegese is ' $n$ voorbeeld van hoe geanaliseerde eenhede sinteties tot 'n koherente geheel gebou word.

Vorster is daarom korrek as hy die histories-kritiese benadering beskou as behorende tot die meganistiese werklikheidsverstaan. Hy gebruik die interpretasie- en epistemologieparameters, asook die masjien as grondmetafoor, om sy standpunt te substansieer: 'This approach is critical in as far as arguments are given for conclusions that are reached. It is objective in as much as the scientific community accepts the methods intersubjectively. It is mechanistic in as far as the parts dominate the whole while the parts fit together like a machine' (Vorster 1988:36). Hy redeneer dat die toenemende beklemtoning van holistiese verstaan op die terrein van die Bybelse hermeneutiek eerder 'n aanduiding is van 'n pre-paradigmatiese stadium op pad na 'normale wetenskap' as dat dit gesien moet word as 'n poging tot restourasie van die histories-kritiese verstaansmodel. 


\section{Holistiese verstaan}

Capra verduidelik soos volg die tekortkomings in die atomistiese ingesteldheid en analitiese metode wat as deel van die meganistiese paradigma nie meer fisici se vrae oor anomalieè toereikend beantwoord nie:

The material world they observed no longer appeared as a machine, made up of a multitude of separate objects, but rather as an indivisable whole; a network of relationships that included the human observer in an essential way. In their struggle to grasp the nature of subatomic phenomena, scientists became painfully aware that their basic concepts, their language, and their whole way of thinking were inadequate to describe this new reality.

(Capra 1988:15)

Hoewel selfs antieke mitiese patrone sowel as moderne wetenskaplike modelle (soos bv die redaksie-kritiek) op 'n manier pogings was om die idee van 'eenheid' (wholeness) te bevredig, is die anomalieë wat mettertyd binne die meganistiese paradigma ervaar is, tog nie beantwoord nie. Bohm begin daarom om 'n implisiete holistiese orde te sien wat ten grondslag lè van alle gefragmenteerde objekte. Hy noem dit 'holomovement' (kyk Martin 1987:371). Die aspek van 'holistiese orde' ontwikkel dus in werklikheid tot 'n status wat veel hoër of liewer veel anders is as wat 'holisme' binne die meganistiese paradigma was.

Insgelyks merk Martin die volgende op wat teenoor die analitiese verstaan en die konstruering van 'n geheelraamwerk op grond van resultate van 'n analitiese of atomistiese werkwyse gesien moet word: 'Wholes have properties that parts do not have' (Martin 1987:377). Kenmerke van sulke holistiese sisteme is dat hulle epistemologie interaktief is en dat objek en subjek, ontologies gesien, dialekties ' $n$ 'mind system' vorm. Met betrekking tot die parameter 'analise' is hierdie sisteme struktureel en vorm dié strukture 'n komplekse, verweefde geheel. Bogenoemde waarnemings ten opsigte van die kwaliteite van die onderskeie parameters (epistemologie, ontologie, analise en bewussyn) geskied interpretatief deur middel van 'n deelnemende bewussyn (kyk Martin 1987:380).

Talbot omskryf in hierdie verband die nut van hologramme vir die beskrywing van die parameter 'bewussyn'. Hologramme word met behulp van laser geskep om, anders as foto's, driedimensionele effekte op 'n tweedimensionele vlak te kan weergee. 'n Interessante eienskap van die hologram is egter dat dit nie gedissekteer kan word soos dit in die meganistiese model die geval is nie. Wanneer die hologram in twee gesny word, is die beeld nie gedeel nie, maar is twee perfekte eenderse beelde geskep. Sny hierdie twee dele elk in die helfte en vier identiese beelde bestaan. Daar kan dus gesê word dat die onderskeie dele elk kwaliteite van die geheel besit. 
'This is intriguing because the same holographic/field relationship also appears to govern the structure of life, and, indeed, the structure of our thinking processses as well' (Talbot 1980:45).

Van Aarde bepleit die handhawing van die Kantiaanse dialektiek met betrekking tot die verhouding tussen subjek en objek baie vurig, veral in soverre dit die ontologiese status van onderskeid tussen God en die mens in die teologie raak. Capra bepleit op sy beurt 'n netwerk van heterargiese 'entiteite' waarin subjek en objek nie langer skeibaar of onderskeibaar is nie. Kenteoreties gesien mond dit vir Van Aarde nie slegs in 'n relativisme uit nie, maar ook wat die Godsbegrip betref, in 'n panteïsme omdat dit nie 'n onderskeid (ook kwalitatief) tussen mens en God tref nie: 'Capra is of the opinion that holism amounts to pantheism' (Van Aarde 1988:58).

Bateson erken dat die aspek 'transendensie' totaal verval en bied as oplossing 'n oorheersende immanensie aan. Schoeman (1990) haal Bateson (1972:461) aan:

The individual mind is immanent not only to the body... and there is a larger Mind of which the individual mind is only a subsystem. This larger Mind is comparable to God, and is perhaps what some people mean by 'God', but it is still immanent in the total interconnected social system and planetary ecology.

Hiervolgens is daar nie meer sprake van transendensie nie. So 'n monistiese denke het enorme implikasies vir die teologie en die Bybelse hermeneutiek. Alles word immanent verklaar, ook die teenwoordigheid van God - meer nog: God word voorgestel as niks meer as die 'larger mind' in terme waarvan die 'individual mind' deur middel van 'n 'deelnemende bewussyn', 'n 'subsystem' is nie. Anders as die dialektiese teologie word God as immanent voorgestel. Die belewenis van God is nie as subjektief teenwoordig nie, maar God gaan op in 'n immanente teenwoordigheid. Hiermee saam verval die relasionele verband en verbond tussen God en mens. God en mens is nie meer duidelik van mekaar te onderskei nie. Kwalitatiewe onderskeid tussen God en mens verval hiermee. Die grense tussen objek en subjek is vloeibaar -en die relasie osmoties (vgl Schoeman 1990). Talbot (1980:124, 188) maak van hierdie vloeibaarheid tussen subjek en objek 'n vervloeiing en stel 'n onderskeidlose, relasielose 'verhouding' voor met die begrip 'omnijective':

The most radical assertion made by the new phisics is surely that the concept of 'participator' replaces 'observer.' As has been pointed out, this lack of division between the observer and the observed presents a view of reality that can best be called omnijective.

(Talbot 1980:122) 
Met behulp van die Oosterse mistiek argumenteer Talbot dat die bewussyn van die deelnemer nie skeibaar is van die realiteit nie. Die monistiese parameter van die voorgestelde holisme is derhalwe duidelik. 'n Kenmerk wat Palmer (1985:242) van die hermeneutiek stel, naamlik dat dit 'n dialektiese ervaring is, verdwyn hier. Daar word ook nie meer onderskeid getref tussen verskillende persepsies van die werklikhede nie - die enigste werklikheid is die een wat met die deelnemende bewussyn saamgestel is.

Vanuit die perspektief van die dialektiese teologie verduidelik Brunner (1963: 70) dat die objek-subjekrelasie in wese die onderbou van die Christelike teologie uitmaak. Rakende die waarheidsbegrip merk hy op dat daar 'n onlosmaaklike verhouding tussen 'objektiver Glaubenswahrheit [Credo] und subjektiver Glaubensaneignung [credo]' is. Van Aarde beklemtoon eweneens die noodsaak van die onderskeid tussen subjek en objek in relasie tot mekaar en daarmee saam die behoud van die transendensie. Hy praat in Kantiaanse terme hieroor: 'Pantheism excludes faith in the "Wholly Other"' (Van Aarde 1988:58). Sy oplossing is dat 'n geheelbeeld van die dele wel belangrik is; hierdie geheelbeeld loop egter nie op 'n nuwe paradigma uit nie, maar eerder op 'n 'special case' van die analitiese paradigma. Hy haal Smuts aan: 'Mechanism makes way for holism in the fullest sense. But its realisation is a matter of degree, and there will probably always remain some residuary feature of Mechanism' (Van Aarde 1988:59).

Van Arckel het ook bepaalde voorbehoude met betrekking tot die holistiese paradigma, hoewel hy 'n groot voorstaander daarvan is. Hy bepleit 'n behoud van die strukturalisme as 'n 'special case' in die holisme. Hy dink nie monisties nie, maar hou aan 'n dualistiese verstaan van die werklikheid-voor-oë vas. Sodoende, meen hy, maak hy ruimte vir die bestaan van die transendensie. Hy onderskei naamlik tussen die binêre pole van syn en skyn in die Platoniese sin van die woord: 'A or the Truth as a possible objective (even ontological) reality is not denied and replaced by the ultimate, but subjectively observed reality, as the reality. I prefer the constructivist position because I believe that the reality is not the reality' (Van Arckel 1988:229).

Hier is dus steeds sprake van die wisselwerking tussen subjek en objek in relasie en selfs ruimte vir dialektiese teologie in relasie-denke!

\section{Bybelse hermeneutiek}

Ten opsigte van Bateson se denke rakende narratiewe en patrone wat met mekaar verweef is, sê Martin: 'It seems no accident that in biblical studies narrative hermeneutics has emerged in this time of shifting paradigms and that literary criticisms and sociology work with larger patterns of connection' (Martin 1987:371). 
Die vraag ontstaan oor watter patrone en velde by hierdie hermeneutiek aansluit, en tot watter mate. Wat domineer op die ou end die paradigmaverskuiwing die Bybelse hermeneutiek, of eksterne faktore? Martin meen dat 'n verskuiwing van waarde-oordele ten grondslag lê aan die klemverskuiwing in byvoorbeeld die sosiologie en kontekstuele teologie, soos bevrydingsteologie en feministiese teologie. Hy verduidelik die teorie van die verskuiwing in paradigmas en sê dan dat dieselfde vooronderstellings ten grondslag lê aan die 'transformational hermeneutical systems' (Martin 1987:372).

Die verskuiwing in waarde-oordele en hoe die verskuiwing in belang van die hermeneutiek verstaan moet word, is nou verwant. Van Aarde (1990a:2) oordeel dat twee strome die denke van Capra beïnvloed het. Daar het naamlik 'n epistemologiese verandering ingetree by die na-sestiger-Capra. Hierdie verandering het te make met twee belange naamlik die transpersonale (ofte wel die kosmiese humanisme) en sosiale betrokkkenheid. Sosiale betrokkenheid vorm juis 'n vooronderstelling van 'n kontekstuele hermeneutiek. 'n Kontekstuele hermeneutiek se primêre kenmerk is dus dat dit sosiologies gekleur is. Hier is moontlik sprake van 'n oorwaardering van resepsie-kritiek. En die resepsie-kritiek maak deel uit van die holistiese paradigma, tesame met ander verstaansmodelle soos die dekonstruktiewe en narratologiese leesstrategieë (kyk egter Van Aarde 1988:50-51).

Wanneer die waardering van die rol van die leser in die verstaansproses bekyk word, kom die parameter 'dinamika' aan die orde. Die gespreksgenote van die bevrydingsteologie, naamlik randpersone en politieke verontregtes (vgl Van Aarde 1990a), maak deel uit van die lesers van tekste. Omdat die parameter 'interpretasie' in terme van die holistiese paradigma postkrities en poststrukturalisties is en omdat 'n deelnemende bewussyn 'n gegewene binne dieselfde model is, behels dit dat genoemde randpersone nie slegs 'n vertrekpunt binne die model word nie, maar dat dit tot die interpretasie verhef word: 'Rather, this participatory praxis is there from the beginning of the interpretive process, because...biblical interpretation in Western society is [and I would add, has always been] a historical-political task' (Martin 1987:380). As gevolg van die Westerse betrokkenheid by die kritiese model, word die resultate van die Westerse interpretasie binne die holistiese paradigma ondergeskik gestel aan die interpretasie van modelle wat die Aufklärung nie as erfenis het nie.

Martin (1987:381) hou Jose Bonino voor as 'n voorbeeld van hoe 'n holistiese lees van die Bybel kan figureer:

With respect to the context of Latin America, he states that "every interpretation of the text which is offered to us (whether as exegesis, or as systematics, or as ethics) must be investigated in relation to the 
praxis out of which it comes... We cannot receive the theological interpretation coming from the rich world without suspecting it and therefore asking what kind of praxis it supports, reflects and legitimizes.

Martin is van mening dat Marx en Freud as 'the two modern masters of the art of suspecting' (Martin 1987:381) die agtergrond vorm van bogenoemde opmerking van Bonino.

\section{Samevatting}

Die feit dat daar toenemende belangstelling in die sosiale, ekologiese en feministiese bewussyn en betrokkenheid by aanverwante organisasies en bewegings voorkom, kan nie ontken word nie. Oor die vraag of hierdie 'nuwe bewussyn ' en nuwe werkwyses 'n nuwe paradigma in wetenskapsbeoefening inlui, bestaan daar meningsverskille. Sommige geleerdes ontken 'n paradigmaverskuiwing, terwyl andere die tekens van 'n verskuiwing waarneem, maar met voorbehoude. Ek meen dat Martin tereg na die huidige situasie kan verwys as 'n 'methodological ferment'.

Beide Vorster en Martin identifiseer voldoende tekens wat daarop dui dat daar in die rigting van 'n nuwe, postkritiese paradigma beweeg word (Vorster 1988:61). Van Arckel aanvaar die verskuiwing na holisme, maar met voorbehoude. Van Aarde meen dat holisme 'n ou filosofie is en nie 'n nuwe een nie. Volgens hom is dit vanweë die anomalieë en tekortkominge in bestaande wetenskaplike metodes makliker om die tradisionele paradigma omver te werp as om 'n nuwe een te konstrueer: 'I doubt that those who would be fit to overthrow would be fit to govern' (Van Aarde 1988:61).

Van Aarde se besware rakende die verlies aan begrip van transendensie in die denke van eksponente van die voorgestelde holisme, moet beantwoord word. Talbot (1980:161) en ander meen dat die holisme eerder meer ruimte vir godsdiens bied as die meganisme. Hy skets hoe die inhoud van daardie godsdiens sal lyk:

Most importantly, the new physics is offering us a scientific basis for religion...But a word of caution: the religion offered by the new physics is not a religion of values or absolute principles...It is a religion of the human consciousness - indeed, of the psycology of the entire universe as a conscious force acting upon itself. In this new religion we will not find the rules of the game so long sought after by philosophers and theologians. What we will find is a glimpse into ourselves, as bit of cosmic hide-and-seek in which we realize that no rules as such can be found. We make the rules. We play the game. 
Hiermee word van die Westerse filosofie afskeid geneem, van dialekties-teologiese denke, die Kantiaanse epistemologie en hermeneutiek waarvan geleerdes soos Dilthey, Bultmann en Gadamer eksponente was en die heel belangrikste, van die Joods-Christelike Godsbegrip. Die nuwe 'mondiale kultuur' (Van Aarde 1988:5253) van die postmoderne wêreld word nou eenmaal gekenmerk deur sy pluraliteit, nie net slegs met betrekking tot praxis en interpretasie nie maar ook met betrekking tot religieuse ervaring. Die vraag is in die laaste instansie na die relevansie van die waardes van die Christendom as sodanig te midde van hierdie pluraliteit.

\section{Gevolgtrekking}

In die lig van wat reeds gesé is, is dit duidelik dat daar ' $n$ behoefte bestaan om 'n geheelverstaan te vind. Oor die stelling dat hierdie geheelverstaan 'n nuwe paradigma inlui, is daar tans nie eenstemmigheid nie. Dit het tot gevolg dat talle teoloë verkies om die meganisme met sy dualismes te handhaaf, omdat dit nie radikaal breek met die tradisionele paradigma (die een wat tot 'n groot mate tydens die reformasie gegeld het) nie.

Soos hierbo reeds genoem, verskil die godsdiens en Godsbeskouing waarvoor die nuwe fisika ruimte laat, radikaal van die konvensionele Joods-Christelike tradisie. Die vraag ontstaan tot watter mate nuwe fisici ruimte laat vir enige Godsbegrip. In lyn met die monistiese metafisika wat Martin, Bateson, Talbot en Lovelock in die Gaia-hipotese (kyk Lovelock 1990:203vv) voorstel, skryf Hawking sy boek oor die verstaan van die heelal, $A$ brief history of time. As inleiding tot Hawking se boek, se Carl Sagan:

This is also a book about God... or perhaps the absence of God. The word God fills these pages. Hawking embarks on a quest to answer Einstein's famous question about whether God had any choice in creating the universe. Hawking is attempting, as he explicitly states, to understand the mind of God. And this makes all the more unexpected the conclusion of the effort, at least so far: $a$ universe with no edge in space, no beginning or end in time, and nothing for the Creator to do.

(Hawking 1990:x; my beklemtoning)

\section{Literatuurvenwysings}

Bateson, G 1972. Steps to an ecology of mind. New York: Ballantine.

Bernstein, R J 1985. Beyond objectivism and relativism. Oxford: Basil Blackwell. Brunner, E 1963. Wahrheit als Begegnung. Zürich: Zwingli Verlag. 
Capra, F 1988. Uncommon wisdom: Conversations with remarkable people. London: Collins.

Descartes, R 1950. Vertoog over de methode. Amsterdam: Wereldbiblioteek.

Fowler, R M 1989. Postmodern Biblical criticism. Forum 5/3, 3-30.

Hawking, S W 1990. A brief history of time: From the big bang to black holes. London: Bantam Press.

Kuhn, T S 1970. The structure of scientific revolutions. 2nd ed. Chicago: Chicago University Press.

Küng, H 1984. Was meint Paradigmenwechsel? in Küng, H \& Tracy, D (Hrsg), Theologie wohin? Auf dem Weg zu einem neuen Paradigma, 19-25. Zürich: Benzinger Verlag.

Lovelock, J 1988. The ages of Gaia: A biography of our living earth. Oxford: University Press.

Martin J P 1987. Toward a post-critical paradigm. NTS 33, 370-385.

Palmer, R E 1969. Hermeneutics. Evanston: Northwestern University Press.

Schoeman M J 1990. Holisme: Die herowering van 'n ou wysheid in 'n moderne konteks. HTS 46, 267-292.

Smuts, J C [1926] 1987. Holism and evolution. Kaapstad: N \& S Press.

Stumpf, S E 1966. Socrates to Sartre. 3rd ed. New York: McGraw-Hill.

Talbot, M 1980. Mysticism and the modern physics. London: Routledge \& Kegan Paul.

Taylor, R 1983. Metaphysics. Ne Jersey: Prentice-Hall.

Van Aarde, A G 1988. Historical criticism and holism: Heading for a new paradigm? in Mouton, J, Van Aarde, A G \& Vorster, W S (eds), Paradigms and progress in theology, 49-64. Pretoria: HSRC.

Van Aarde, A G 1990a. Kenteoretiese opmerkings oor kontekstuele hermeneutiek. Referaat gelewer voor die Subgroep Hermeneutiek van die Nuwe Testamentiese Werkgemeenskap van Suid Afrika, Universiteit van Stellenbosch.

Van Aarde A G 1990b. Organismic holism in the light of the modernity-postmodernity debate. Paper dellivered at the HSRC-Conference on the Relevance of theology in the 1990's, University of Stellenbosch.

Van Arckel, J G de J 1988. Theology beyond Newton: A quantum leap, in Mouton, $\mathrm{J}$ et al (eds), Paradigms and progress in theology, 223-238. Pretoria: HSRC.

Vorster, W S 1988. Towards a post-critical paradigm: Progress in New Testament scolarship? in Mouton, $\mathrm{J}$ et al (eds), Paradigms and progress in theology, 31-48. Pretoria: HSRC. 